\title{
Plant Growth Regulators Affecting Leaf Traits of Loquat Seedling
}

\author{
Muhammad Imam Surya ${ }^{{ }^{\star}}$, Lily Ismaini ${ }^{1}$, Suluh Normasiwi ${ }^{1}$ \\ Dwinda Mariska Putri ${ }^{1}$ and Vandra Kurniawan ${ }^{1}$
}

${ }^{1}$ Research Center for Plant Conservation and Botanic Gardens, Indonesian Institute of Sciences, Jalan Kebun Raya Cibodas, P.O.Box 19, Cipanas-Cianjur 43253, West Java, Indonesia.

Authors' contributions

This work was carried out in collaboration among all authors. Author MIS supervised the whole research work, contributed in data analysis and wrote the first draft of the manuscript. Authors MIS, $V K, D M P, L I$ and SN planned the research work, performed the experiment, did the sampling and analyses. All authors read and approved the final manuscript.

Article Information

DOI: $10.9734 / A R R B / 2020 / v 35 i 1130301$ Editor(s):

(1) Dr. Layla Omran Elmajdoub, Misurata University, Libya. Reviewers:

(1) Rickardo Léo Ramos Gomes, Farias Brito University Center, Brazil. (2) Hamid Ahani Mporg, University of Sari Agricultural Sciences and Natural Resources (SANRU), Iran. Complete Peer review History: http://www.sdiarticle4.com/review-history/62125

Original Research Article

Received 15 August 2020

Accepted 20 October 2020

Published 18 November 2020

\section{ABSTRACT}

Leaf is a key functional traits that shows respond of changes in plant physiology. This experiment aimed to study the changes on the leaf traits of loquat seedling that treated with plant growth regulators (PGRs). Three types of PGRs, auxin (naphthalene acetic acid/NAA), gibberellin (gibberellic acid/GA3) and cytokinin (benzylaminopurine/BA) with four doses (0, 25, 50, $100 \mathrm{ppm}$ ) were sprayed onto the leaves of loquat seedling. We observed nine parameters, PGRs treatments were significantly affecting eight parameters, while there were one parameter is not significantly affected. The results showed that either in mature or young leaves, PGRs treatments were significantly affecting in eight parameters the growth and development of leaves, such as leaf surface area, specific leaf area, fresh and dry weight leaf, water content, number of stomata, size of stomata, chlorophyll and transpiration rate compared to control. These results gave general view that PGRs treatment might stimulate leaf growth and development including photosynthesis and respiration. However, PGRs was not significantly affecting the number of stomata in young leaves. The application of PGRs doses was not always inline with the mean value of each parameters and 
it could be linear or quadratic models. The findings of this research could provide the recommendation for application of PGRs during seedling growth, and theoretical basis for comparison between mature and young leaves after PGRs application.

Keywords: Loquat; plant growth regulators; auxin; gibberellin; cytokinin; leaf.

\section{INTRODUCTION}

Loquat (Eriobotrya japonica Lindl. DOMAIN: Eucarya Archaeplastida; KINGDOM: Viridiplantae (Plantae) Embryophyta; PHYLUM: Angiospermophyta: CLASS: Magnoliopsida; ORDER: Rosales; FAMILY: Rosaceae; GENUS: Eriobotrya) is a subtropical evergreen tree native to southeastern China [1], but well suited to colder Mediterranean Basin areas. The annual loquat cycle runs counter to that of the various temperate fruit crops as it blooms in autumn, develops its fruits during winter and ripens them in early spring [2]. The fruits have yellow-orange color with brown seeds as they ripe and also high sugar, acid and pectin content [3]. Loquat become an important commercial crop in several countries [4]. One of the important factors is that the potential of loquat as a fruit crop. It is due to loquat has phytonutritional composition such as phenolics, triterpenes, flavonoids, organic acids, vitamins, protein, starch, tannins, and minerals $[5,6]$. Plant hormone affects plant growth and development either directly or indirectly.

Plant hormones are a unique cluster of compounds that during this experiment, form one of a topic with specific metabolism and properties. Their only general characteristics are that they are natural compounds in plants with capable of influencing physiological processes at concentrations way below those where these processes will be influenced either nutrients or vitamins [7]. Furthermore, because if complex and complicated self-regulated mechanisms, the manipulation of physiological processes in plants remains a challenge. Manipulating plant processes also remains a challenge, including the increased endogenous level of hormone with the application of plant growth regulators (PGRs) and bio-stimulants, to boost particular plant characteristics [8]. They might act within the tissue of production or translocated to another target tissues [9]. Peleg and Blumwald [10] reported that in the ability of plants to adapt to changing environments by mediating growth, development, nutrient allocation and source or sink transfer, plant hormones play crucial roles. Leaves is a major organ that has function as a source in all vascular plants. For the growth of axial polarity and plant tissue, auxin signal is important. It is also involved in some organogenesis from the apical meristem shoot to the lateral root formation. Cytokinins have been shown to have effects on many other physiological and developmental processes, such as seed germination, bud dormancy, leaf senescence, nutrient mobilization, floral development, apical dominance, the formation and activity of shoot apical meristems. Moreover, the application of gibberellin induces internodal elongation during a wide selection of species. However, in dwarf and rosette species, as well as members of the family Poaceae, the most dramatic simulations are seen. Exogenous GA3 in dwarf plants induces such intense stem elongation that they resemble the tallest varieties of the same species [11].

Leaves are the main photosynthetic organs of plants that play a primary role in photosynthesizing carbohydrates [12] therefore, a number of biological processes such as plant growth, survival, reproduction, and ecosystem function are fully influenced by leaf size e.g. leaf surface area, leaf length and leaf dry mass $[13,14]$. Moreover, stomata are cell structures in the epidermis of tree leaves and needles that are involved in the exchange of gas and water with the environment and also closely associated with processes in plant physiology activities such as transpiration, respiration and photosynthesis $[15,16]$. Plants transpiration also affected by the anatomy of the stomatal complex [17]. Dodd [18] reported that both environmental and hormonal factors and their interactions are able to affect stomatal behavior. Leaf stomata have significantly distinct characteristics, such as size, shape, and density in various plants [19]. Miyazawa et al. [20] reported that stomata development in young leaves is correlated with the stomatal activity of mature leaves. In the other hands, chlorophyll plays an essential role in the photosynthetic process. The content of chlorophyll pigments in the leaf tissue is thus a major determinant of overall photosynthetic efficiency and directly influences to plant growth and development [21]. Even though some studies have been conducted on the effect of PGRs on plant growth and development, but only 
few studies on the effect PGRs on morphological character of mature and young leaves development. In order to determine the effect of PGRs, this experiment was aimed to study the influences of plant growth regulators on stomata, leaf, chlorophyll and transpiration rate in mature and young leaves of loquat.

\section{MATERIALS AND METHODS}

\subsection{Plant Material and Treatments}

The study was conducted on August to December 2019 at the green house and laboratory of Cibodas Botanical GardenIndonesian Institute of Sciences. The seedlings of loquat were obtained from Samosir, North Sumatra. It was propagated on November 2018. After six months, the seedlings were transferred to the new polybag contain humus and burnt husk (1:1). Three types of PGRs i.e. NAA (naphthalene acetic acid), GA3 (gibberellic acid) and BA (benzylaminopurine), with four different concentrations 0 ppm (control), 25 ppm, 50 ppm and $100 \mathrm{ppm}$ were applied to the seedling of loquat by spraying into the leaves. Two days after the treatment, young and mature leaves were collected and continued for further observation of some characters such as chlorophyll, leaf surface area and leaf weight, transpiration rate and stomata traits.

\subsection{Leaf Surface Area, Leaf Weight, Specific Leaf Area and Chlorophyll Measurements}

Leaf surface area was calculated using image $\mathrm{J}$ software. Moreover, leaf weight measurement was divided into fresh and dry weight of leaves. Fresh weight of leaf measured right after sample was collected. Dry weight measured after leaf placed in $60^{\circ} \mathrm{C}$ oven for 72 hours. Specific leaf area (SLA) is the one-sided area of a fresh leaf, divided by its dry mass. The leaf water content was calculated as following: Water content $(\%)=$ ((Fresh weight - Dry weight)/Fresh weight) $\times 100$. The chlorophyll content $\left(\mu \mathrm{g} / \mathrm{cm}^{2}\right)$ measured with field portable chlorophyll meter (SPAD-502 Plus, Konica Minolta, INC. Japan).

\subsection{Transpiration Rate}

Transpiration rate was measured using cobalt chloride paper method. Cobalt chloride paper was a thin filtered paper with the size of $1 \mathrm{~cm}$ wide and $6 \mathrm{~cm}$ long. The paper was dried in the oven before measurement until its color was blue. Cobalt chloride paper placed on the abaxial surface of a leave, covered with two glass slides. The time for the paper changed its color from blue to pink was recorded [22].

\subsection{Stomatal Frequency}

Stomata were observed by generating a nail polish leaf impression on a slide. The fresh leaves were cleaned with tissue and masking tape to remove the trichomes from leaf. A thin layer of nail polish was applied and spread evenly on the lower foliar surface, and allowing it to dry out. The dried nail polish was carefully peeled off from the foliar, and the shadow cast replicas were mounted under an optical microscope on glass slides to be examined under. The observation was done using an optical microscope (Olymphus CX22LED) at 40x magnification with a field of view approximately $262.71 \times 197.66 \mu \mathrm{m}$. Image analysis of the stomata was carried out using an image analyzer Image raster 3.0.

\subsection{Statistical Analysis}

Data were analyzed using SPSS 16.0 and reported in form of box plots. The Normality (Shapiro-Wilk normality test) testing was done followed the Pearson correlation coefficient among parameters. Means were calculated and compared from each treatment.

\section{RESULTS AND DISCUSSION}

\subsection{Leaf Surface Area}

In general, leaf surface area of mature leaves is largest than young leaves (Fig. 1). In the mature leaves, the largest mean value of leaf surface area was shown on treatments of NAA (28.61 $\left.\mathrm{cm}^{2}\right)$ followed by control $\left(27.37 \mathrm{~cm}^{2}\right)$, GA3 $(27.00$ $\left.\mathrm{cm}^{2}\right)$, BA $\left(22.14 \mathrm{~cm}^{2}\right)$. Moreover, the highest value of leaf surface area in mature leaves was NAA $25\left(34.49 \mathrm{~cm}^{2}\right)$ and the lowest was BA 25 $\left(16.55 \mathrm{~cm}^{2}\right)$.

In the other hands, the largest mean value of leaf surface area for young leaves was shown on the treatments of NAA $\left(8.00 \mathrm{~cm}^{2}\right)$ followed by GA3 $\left(7.39 \mathrm{~cm}^{2}\right)$, BA $\left(7.34 \mathrm{~cm}^{2}\right)$, control $\left(6.29 \mathrm{~cm}^{2}\right)$. The highest value of leaf surface area in young leaves was BA $100\left(10.29 \mathrm{~cm}^{2}\right)$ and the lowest was GA3 $25 \quad\left(3.31 \mathrm{~cm}^{2}\right)$. Bishnoi and Krishnamoorthy [23] reported that application of GA3 increased leaf surfaces and another study reported by Nobel et al. [24] that leaf surface 
area was related to the mesophyll area and it could be affecting the photosynthetic rate.

\subsection{Specific Leaf Area}

We found there are more variety of specific leaf area of young leaves than mature leaves (Fig. 2). The highest value in young leaves was control $\left(227.39 \mathrm{~cm}^{2} \mathrm{~g}^{-1}\right)$ and the lowest was GA3 25 treatment $\left(124.89 \mathrm{~cm}^{2} \mathrm{~g}^{-1}\right)$. Moreover, in mature leaves, the highest value was GA3 50 (164.26 $\left.\mathrm{cm}^{2} \mathrm{~g}^{-1}\right)$, and the lowest was BA $100\left(100.94 \mathrm{~cm}^{2}\right.$ $\left.\mathrm{g}^{-1}\right)$. The treatments of PGRs on mature leaves was able to increase the mean value of SLA i.e. GA3 $\left(146.99 \mathrm{~cm}^{2} \mathrm{~g}^{-1}\right)$ followed by NAA $(137.13$ $\left.\mathrm{cm}^{2} \mathrm{~g}^{-1}\right)$, BA $\left(135.74 \mathrm{~cm}^{2} \mathrm{~g}^{-1}\right)$, control $\left(127.54 \mathrm{~cm}^{2}\right.$ $\left.g^{-1}\right)$.

In the opposite, PGR's could be reducing the mean value of SLA in young leaves i.e. control $\left(227.39 \mathrm{~cm}^{2} \mathrm{~g}^{-1}\right)$ followed by BA $\left(170.96 \mathrm{~cm}^{2} \mathrm{~g}^{-1}\right)$,

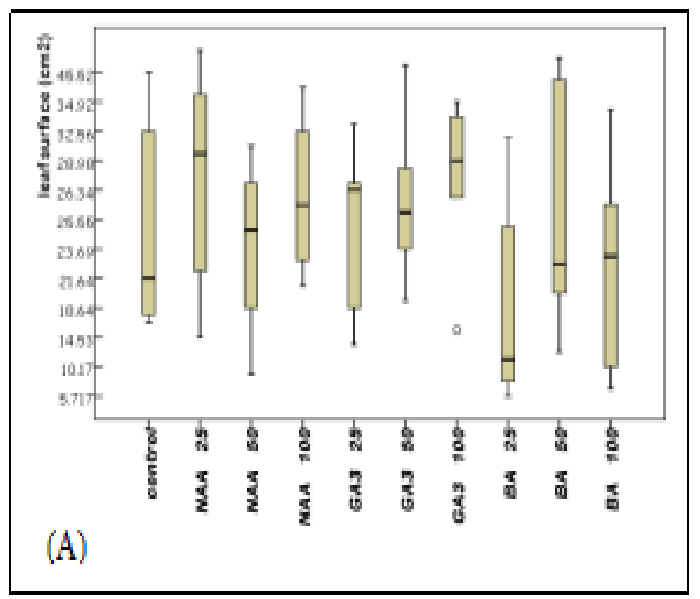

GA3 $\left(146.85 \mathrm{~cm}^{2} \mathrm{~g}^{-1}\right)$, NAA $\left(143.49 \mathrm{~cm}^{2} \mathrm{~g}^{-1}\right)$. Miceli et al. [25] reported that a significant increase in the specific leaf area was found with increasing GA3 concentration in lettuce.

\subsection{Fresh and Dry Leaf Weight}

Generally, fresh and dry leaf weight in mature leaves was higher than young leaves. Fresh and dry leaf weight was affected by PGRs, either in mature or young leaves (Fig. 3 and Fig. 4). The PGRs treatments produced fresh and dry leaf weight in young leaves greater than control, i.e. NAA $(0.235 \mathrm{~g}$ and $0.055 \mathrm{~g})$, GA3 $(0.217 \mathrm{~g}$ and $0.050 \mathrm{~g}), \mathrm{BA}(0.195 \mathrm{~g}$ and $0.046 \mathrm{~g})$ and control $(0.120 \mathrm{~g}$ and $0.040 \mathrm{~g})$. In the opposite for mature leaves, control produced fresh and dry weight smaller than PGRs treatments, i.e. control $(0.580$ $\mathrm{g}$ and $0.250 \mathrm{~g})$, NAA $(0.496 \mathrm{~g}$ and $0.211 \mathrm{~g})$, GA3 $(0.486 \mathrm{~g}$ and $0.203 \mathrm{~g})$ and BA $(0.429 \mathrm{~g}$ and $0.179 \mathrm{~g})$.

Fig. 1. Leaf surface area of loquat seedling in mature (A) and young (B) leaves
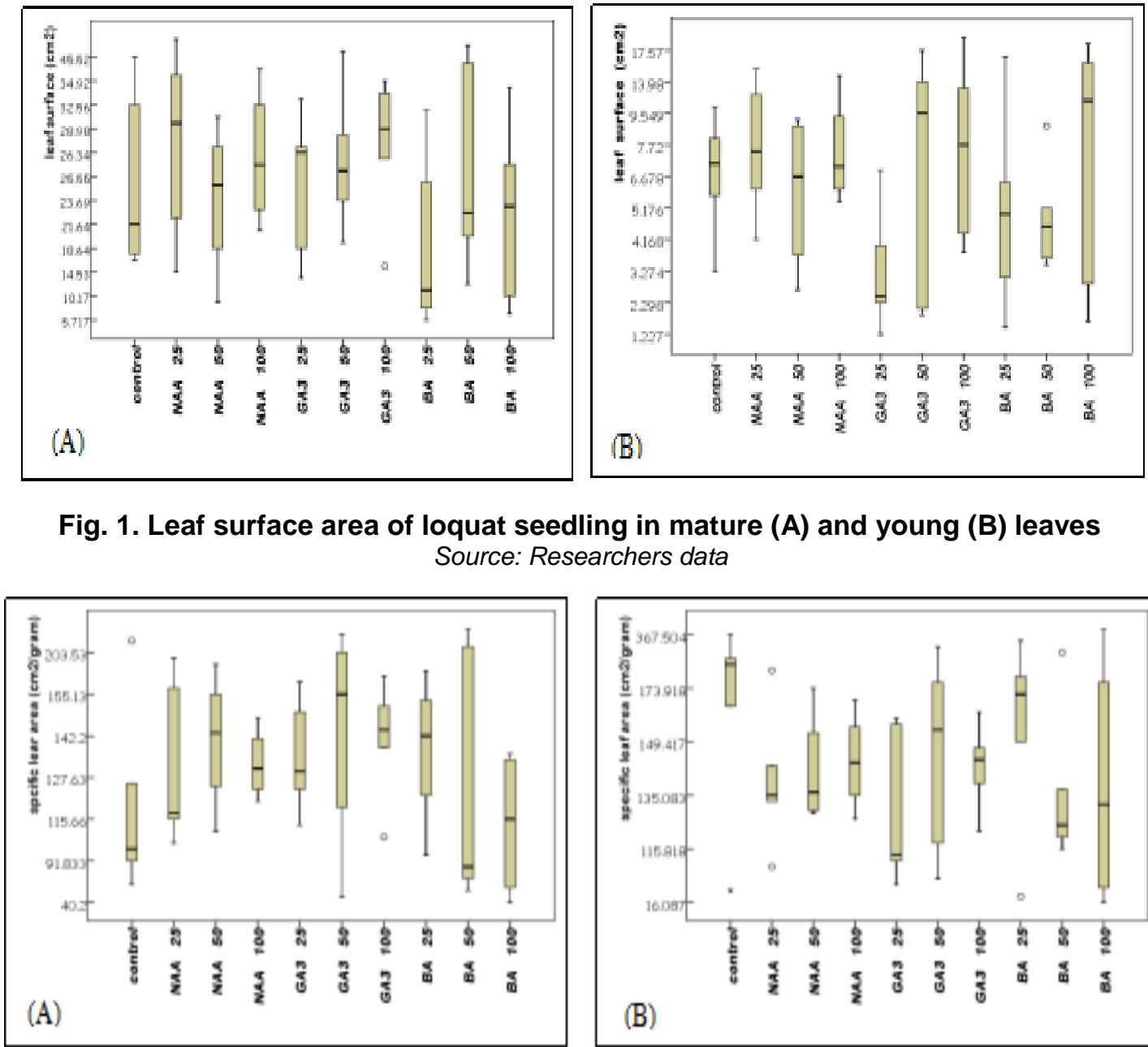

\section{Source: Researchers data}

Fig. 2. Specific leaf area of loquat seedling in mature (A) and young (B) leaves Source: Researchers data 

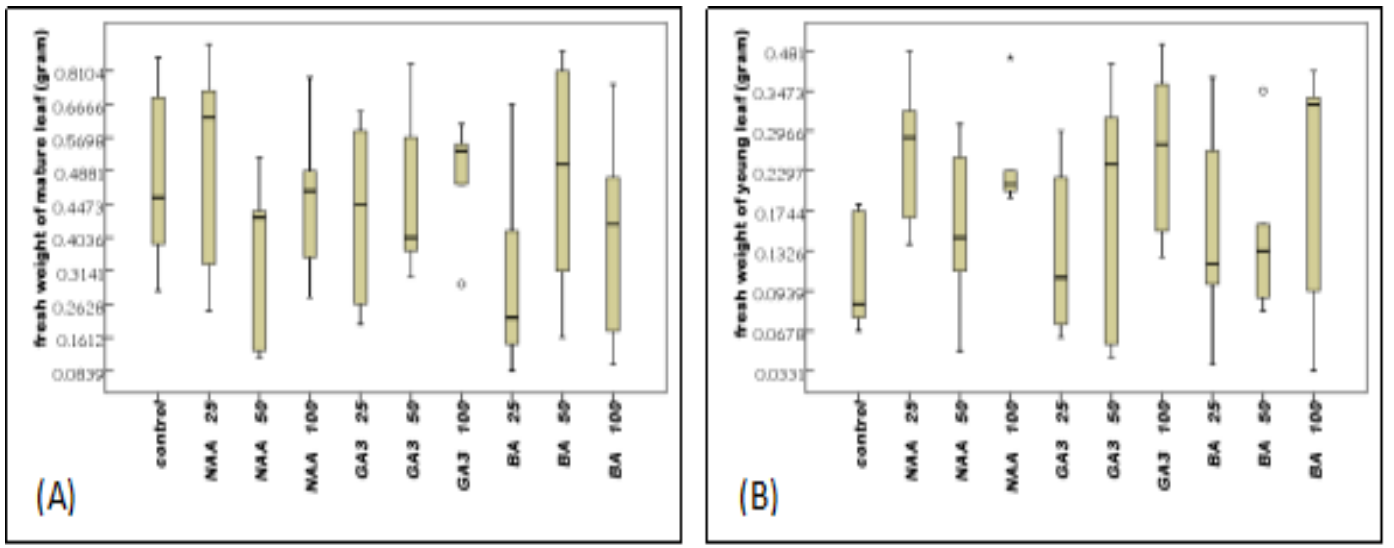

Fig. 3. Fresh weight of mature (A) and young (B) leaves of loquat
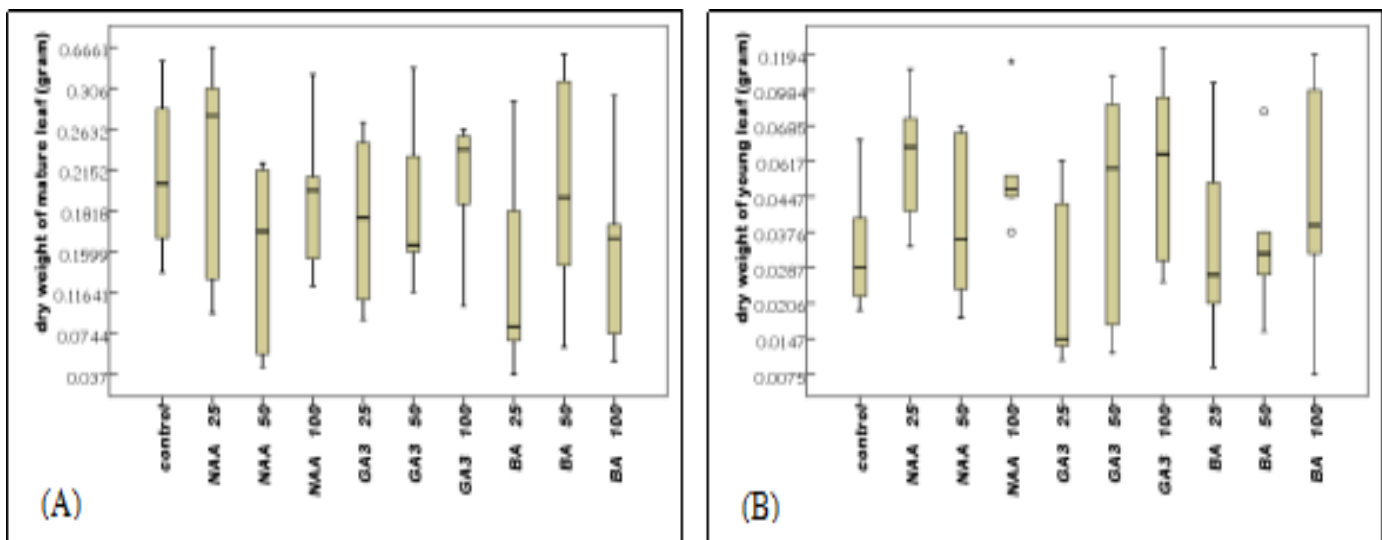

Fig. 4. Dry weight of mature (A) and young (B) leaves of loquat Source: Researchers data
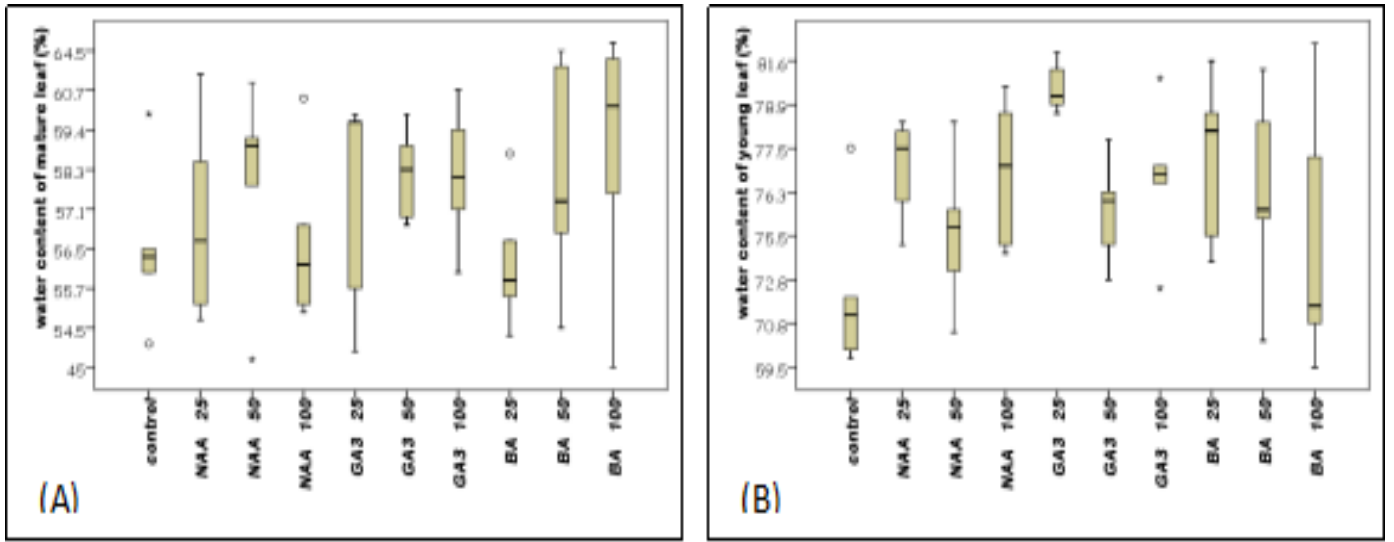

Fig. 5. Percentage of water content in mature $(A)$ and young $(B)$ leaves Source: Researchers data

Moreover, Lambers et al. [26] reported that cytokinin plays a major role in the shift in biomass allocation from leaves to roots, but there is no information to support a role of cytokinin in the changes in leaf anatomy.

\subsection{Water Content}

Percentage of water content was higher in young leaves than in mature leaves. The GA3 $(77.71 \%)$ treatment produced the higher percentage of 
water content in young leaves and followed by NAA $(76.21 \%)$, BA $(75.98 \%)$, control $(69.81 \%)$. Dwyer et al. [27] reported that GA3 treatment could be increasing the relative water content in lemonwood.

Our results showed that the lower doses of PGRs used will producing highly water content of young leaves. The GA3 25 (80.86\%) treatment produced the highest percentage of water content than the other treatments. Moreover, in mature leaves (Fig. 5), the BA (59.55\%) treatment produced the higher percentage of water content and followed by GA3 (57.96\%), NAA $(57.45 \%)$, control $(56.34 \%)$. The results showed that higher doses of BA and GA3 would be increasing the percentage of water content but inversely on NAA treatment. The highest and lowest percentage of water content in mature leaves was shown on BA 100 (63.24\%) and BA $25(56.27 \%)$ treatments.

\subsection{Chlorophyll Content}

Our results showed that the chlorophyll content in mature leaves was higher than young leaves. At control plants, either in mature (control 58.10 $\mu \mathrm{g} / \mathrm{cm}^{2}$; NAA $57.86 \mu \mathrm{g} / \mathrm{cm}^{2}$; GA3 $57.01 \mu \mathrm{g} / \mathrm{cm}^{2}$; BA $55.38 \mu \mathrm{g} / \mathrm{cm}^{2}$ ) and young (control 38.93 $\mu \mathrm{g} / \mathrm{cm}^{2}$; NAA $38.51 \mu \mathrm{g} / \mathrm{cm}^{2}$; BA $38.12 \mu \mathrm{g} / \mathrm{cm}^{2}$; GA3 $35.37 \mu \mathrm{g} / \mathrm{cm}^{2}$ ) leaves has highest content of chlorophyll compared than other treatments. Fig. 6 showed that the NAA $25\left(59.73 \mu \mathrm{g} / \mathrm{cm}^{2}\right)$ treatment produced the highest chlorophyll content for mature leaves, and NAA 50 (41.29 $\mu \mathrm{g} / \mathrm{cm}^{2}$ ) for young leaves.

Mbandlwa et al. [28] reported that PGR's affected leaf chlorophyll content. However, our results showed that PGR's treatment was not always significantly increasing chlorophyll content.

\subsection{Number of Stomata}

The number of stomata in mature leaves was higher than young leaves. The growth hormones such as auxin and kinetin are also registered increase in the number of stomata [29]. Fig. 7 showed that either in mature or young leaves, the BA treatment (30.16 and 9.38) produced higher number of stomata and followed by control (30.12 and 9.33), GA3 (28.78 and 9.15), NAA (22.27 and 9.07).

Moreover, the highest number of stomata in mature and young leaves was showed by BA 50
(42.67) and GA3 25 (9.58) treatments. The lowest number of stomata in mature and young leaves was showed by GA3 25 (9.58) and GA3 50 (8.18) treatments.

\subsection{Size of Stomata}

The results indicated that the size of stomata in mature leaves was larger than young leaves. Fig. 8 showed that the GA3 $\left(949.104 \mathrm{~mm}^{2}\right)$ treatment produced larger stomata in mature leaves and followed by NAA $\left(873.973 \mathrm{~mm}^{2}\right)$, control $\left(865.290 \mathrm{~mm}^{2}\right)$, BA $\left(813.721 \mathrm{~mm}^{2}\right)$. The largest and smallest size of stomata in mature leaves was showed by NAA $100\left(1047.816 \mathrm{~mm}^{2}\right)$ and BA $100\left(726.536 \mathrm{~mm}^{2}\right)$ treatments. Furthermore, in young leaves, NAA $\left(381.987 \mathrm{~mm}^{2}\right)$ treatment produced the largest stomata and followed by the other treatments such as GA3 $\left(322.033 \mathrm{~mm}^{2}\right)$, control $\left(284.400 \mathrm{~mm}^{2}\right)$ and BA $\left(240.656 \mathrm{~mm}^{2}\right)$. The largest and smallest size of stomata in young leaves was showed by NAA 50 (416.390 $\left.\mathrm{mm}^{2}\right)$ and BA $50\left(169.640 \mathrm{~mm}^{2}\right)$ treatments.

These effects of an auxin or a cytokinin was inline with Di Benedetto et al. [30] which is IAA or BAP sprays also increased epidermal cell and sizes of stomata. However, Savaldi-Goldstein and Chory [31] suggestion, which indicated that the epidermal layer was the preferred target for auxin action on leaves, does not support the fact that the main effect of an IAA spray on leaf anatomy was to increase the amount of inter cellular spaces.

\subsection{Transpiration Rate}

Transpiration is a process of water movement through the stomata of plant. The transpiration rate occurs while the amount of water lost from the plants through the opening and closing of stomata at the specific time period. Jones [32] showed that the transpiration rate is mainly controlled by stomatal movement but stomata size and density are also affected.

Moreover, Kumar et al. [33] reported that foliar spray of IAA, GA3, and BAP resulted a raise in photosynthetic rate, transpiration rate and stomatal conductance. Our results on Fig. 9 showed that NAA $(2.046 \mathrm{mg} / \mathrm{h})$ treatment has higher transpiration rate and followed by control $(1.560 \mathrm{mg} / \mathrm{h})$, GA3 $(0.977 \mathrm{mg} / \mathrm{h})$, BA $(0.685$ $\mathrm{mg} / \mathrm{h}$ ). Moreover, the highest and lowest transpiration rate in the seedling of loquat shown on NAA $50(2.176 \mathrm{mg} / \mathrm{h})$ and BA $100(0.651$ $\mathrm{mg} / \mathrm{h}$ ) treatments. Spray of BA could be 
decreasing the transpiration rates. Its due to $B A$ has an anti-transpiratory activity. Schubert et al. [34] reported that spraying of BA can reduce water consumption thus it can be used to protect crop plants from chilling or freezing stress.

\subsection{Correlation}

In our study, there was a positive and negative correlation between some parameters such as, leaf weight, SLA, leaf surface, stomata, water content, chlorophyll and transpiration rate. Table 1 showed that fresh and dry weight leaf are highly correlate. SLA in mature leaf was not affected by leaf surface, but has correlation with SLA of young leaf. In the other hands, SLA in young leaves affected by leaf surface. Either in mature or young leaves, the SLA value has a negative correlation with water content. Kuldeepsingh [35] reported that there is an interaction between SLA, relative water content and genotype to the chlorophyll content. Our study showed that chlorophyll content in mature leaves was affected by leaf weight and water content, but chlorophyll content in young leaves affected by leaf surface, SLA and percentage of water content. Moreover, stomata is an important organ on the process of photosynthesis. Our results showed that numbers of stomata in mature leaves were influencing the transpiration rate, but it's not in young leaves. The size of stomata was affected by leaf surface area and influenced to dry weight, chlorophyll content and transpiration rate in mature leaves. In the other hands, stomatal size of young leaves has a negative correlation with stomatal size of mature leaves. Miyazawa et al. [20] reported that number of stomata per leaf increased steadily with the expansion of the leaf area, reaching a maximum value by the time the leaf area had reached approximately half its final value. However, as the leaf area increased without the concurrent change in stomatal number, the stomatal density decreased. Zhang et al. [36] reported that stomatal conductance, photosynthetic and transpiration rate declined during water stress in mature and young leaves.

The hormones of plants play a significant role in the regulation of growth processes for leaves morphology and development. Auxin, gibberellin, and cytokinin are plant hormones that play roles in the growth and development of leaves. From these results, it appears that the PGR's treatment such as NAA, GA3 and BA could be significantly affecting leaf area, SLA, water content, leaf weight chlorophyll, stomata and transpiration rate in the seedling of loquat. In this experiment the parameters used to determine the effect of PGR which is related to the photosynthesis. Although the rate of photosynthesis was not observed, these experiments gave a general view that PGR's treatment might stimulate leaf growth and development include photosynthesis and respiration. Moreover, synthesis of plant secondary metabolites is influenced by exogenous phytohormones such as GA3, IAA and ABA [37].

Furthermore, number of stomata gave an opposite result with size of stomata. The size of stomata in the treatment of NAA and GA3 was larger than BA treatment or control. However, the number of stomata in the treatment of NAA and GA3 smaller than BA treatment or control. It means that each hormone gave different effect for plant growth and development. The exogenous application of specific hormones, which may not always replicate the effects of changes in endogenous hormone levels, has examined the functions of several hormones in stomatal function. Moreover, there may be different exogenous and endogenous effects between tissue types and species. Simultaneous quantification of different phytohormones in guard cells during open and closed conditions would provide a more objective view concerning their positions in stomatal functions [38]. It would also be important to determine the stomatal function and the regulatory roles more extensively in different hormones.

Gibberellin controls various developmental processes during the plant's life cycle, from seed germination through leaf expansion, stem elongation, flower induction, and seed development [39]. Furthermore, the mode of action of gibberellin in plants is still not well known, as variety of positive and negative functional interactions with other endogenous and environmental reactions. Weis and Ori [40] suggest that interactions with other hormones play major roles in the action of gibberellin, which involves the existence of effective and responsive cross-talk mechanisms among the corresponding signaling pathways. Moreover, the functions of gibberellin and auxin correlate with the regulation of cell expansion and tissue differentiation. Auxin affects both gibberellin signaling and gibberellin biosynthesis. In the other hands, gibberellin and cytokinin have antagonistic effects on various development processes. Reciprocal interactions are regulated at both biosynthesis and signal transduction stages. 

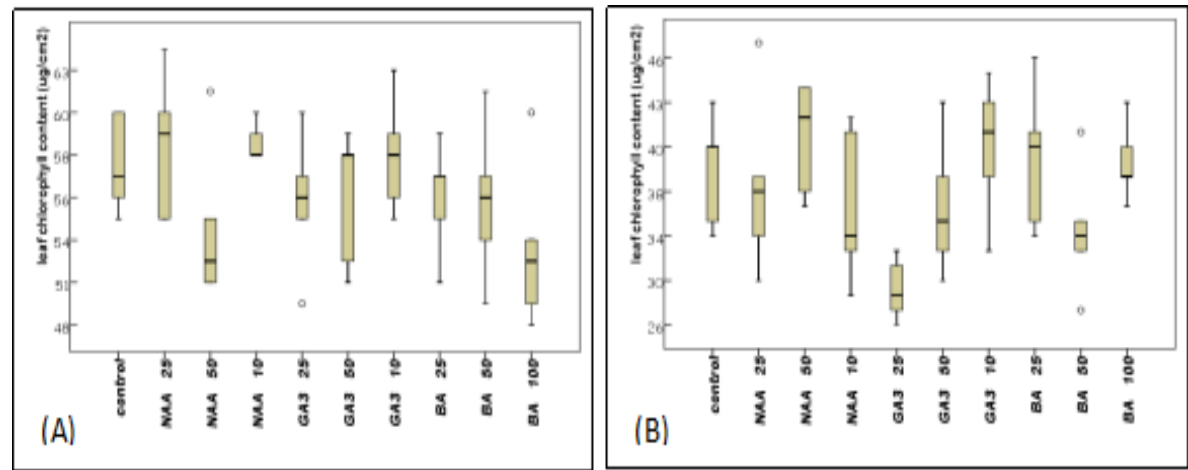

Fig. 6. Chlorophyll content of loquat in mature (A) and young (B) leaves Source: Researchers data
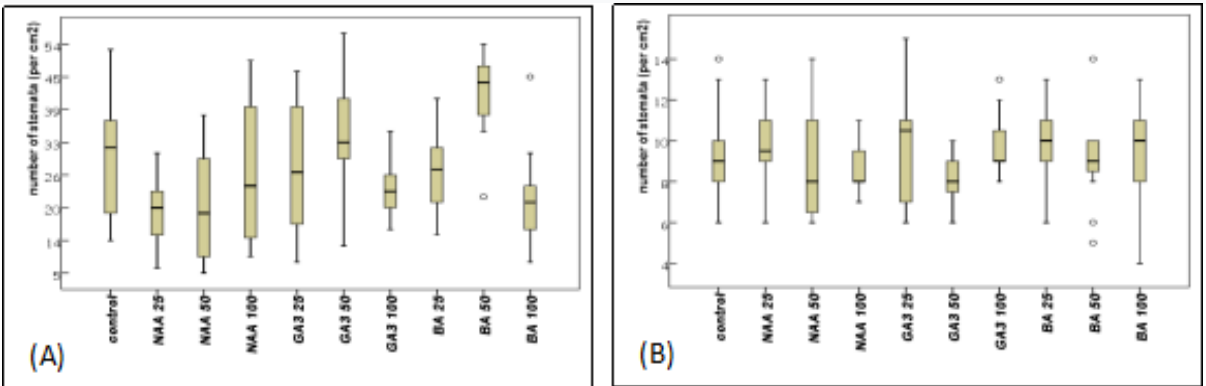

Fig. 7. Number of stomata in mature (A) and young (B) leaves of loquat Source: Researchers data
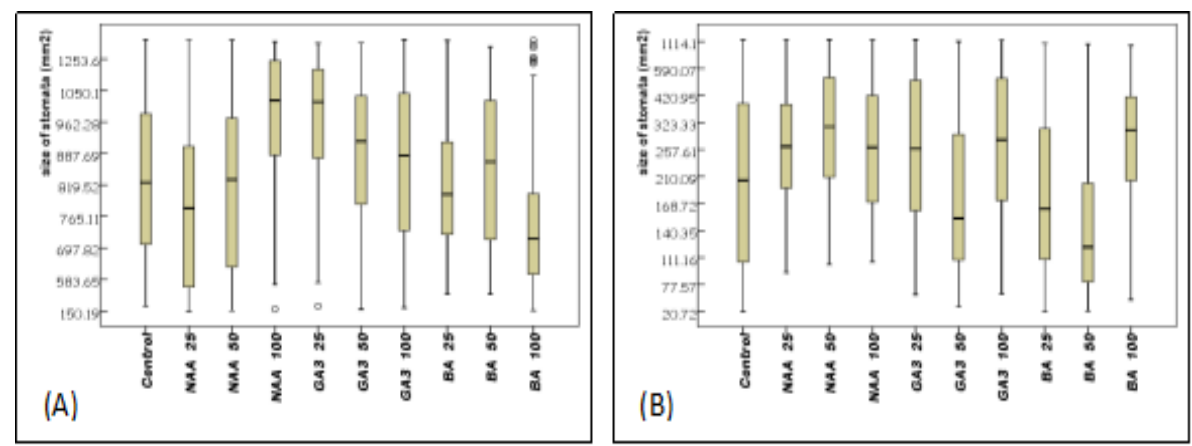

Fig. 8. Size of stomata in mature (A) and young (B) leaves of loquat Source: Researchers data

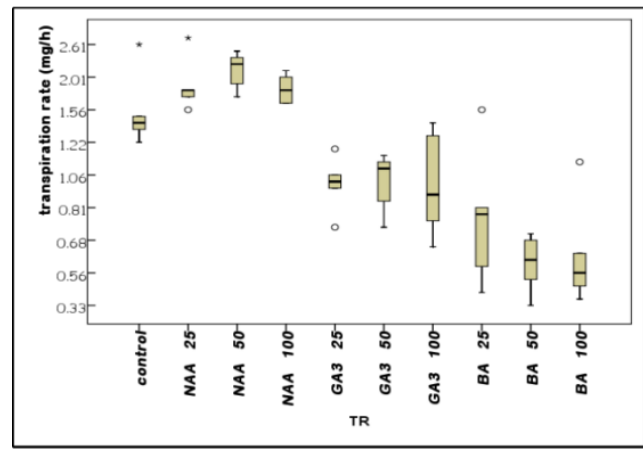

Fig. 9. Transpiration rate of loquat seedling Source: Researchers data 
Table 1. Correlation value between parameters of leaf traits in loquat

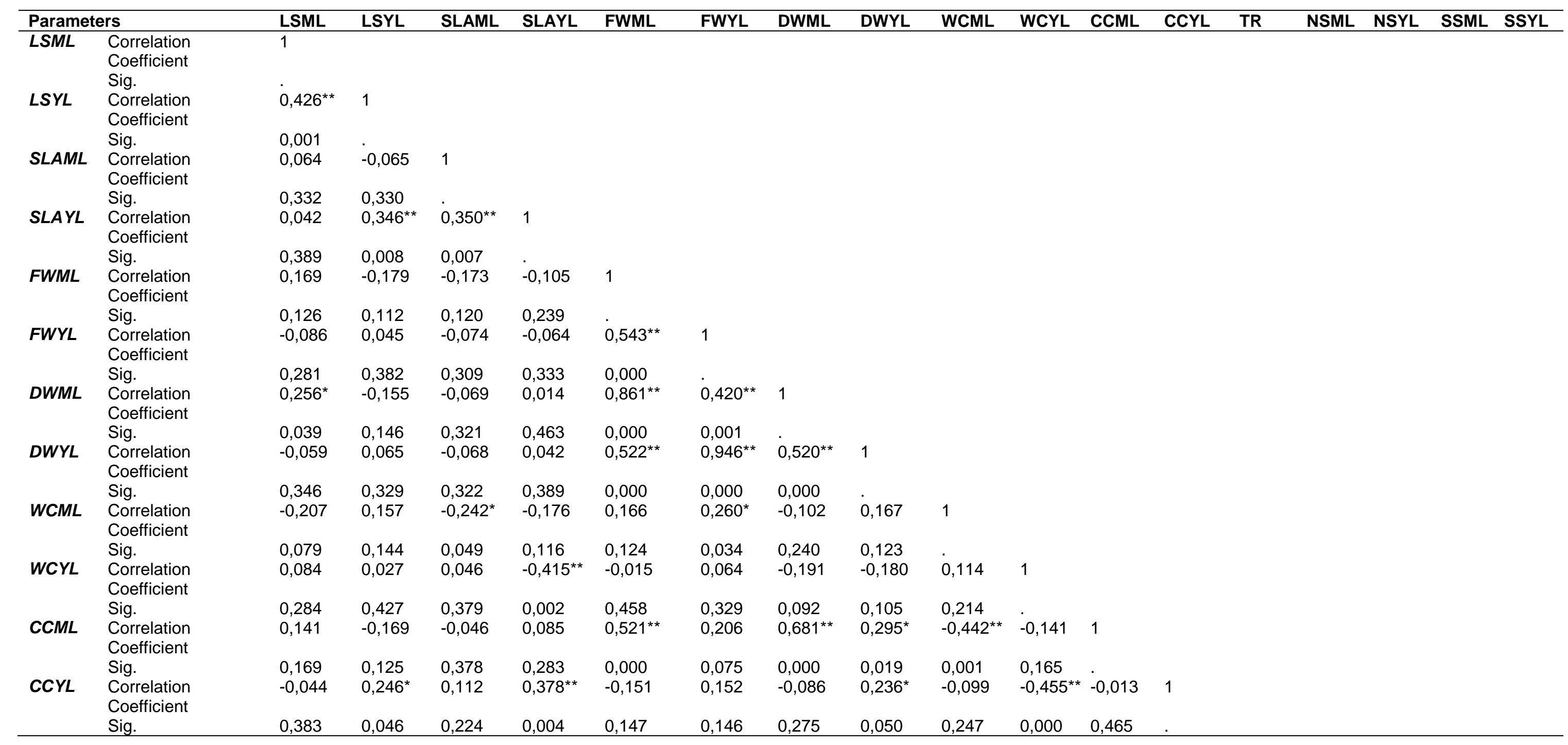




\begin{tabular}{|c|c|c|c|c|c|c|c|c|c|c|c|c|c|c|c|c|c|}
\hline \multicolumn{2}{|c|}{ Parameters } & LSML & LSYL & SLAML & SLAYL & FWML & FWYL & DWML & DWYL & WCML & WCYL & CCML & CCYL & TR & NSML & NSYL & SSML SSYL \\
\hline \multirow[t]{2}{*}{$T R$} & $\begin{array}{l}\text { Correlation } \\
\text { Coefficient }\end{array}$ & 0,047 & $-0,030$ & 0,152 & $-0,016$ & 0,021 & 0,076 & 0,081 & 0,157 & $-0,236^{*}$ & $-0,120$ & 0,184 & 0,025 & 1 & & & \\
\hline & Sig. & 0,375 & 0,419 & 0,152 & 0,458 & 0,442 & 0,299 & 0,288 & 0,137 & 0,049 & 0,203 & 0,100 & 0,432 & & & & \\
\hline NSML & $\begin{array}{l}\text { Correlation } \\
\text { Coefficient }\end{array}$ & $0,267^{*}$ & 0,103 & 0,123 & $-0,113$ & 0,018 & $-0,073$ & 0,025 & $-0,050$ & $-0,126$ & 0,092 & 0,062 & $-0,235^{\star}$ & $0,317^{*}$ & 1 & & \\
\hline NSYL & $\begin{array}{l}\text { Sig. } \\
\text { Correlation } \\
\text { Coefficient }\end{array}$ & $\begin{array}{l}0,033 \\
0,005\end{array}$ & $\begin{array}{l}0,243 \\
-0,086\end{array}$ & $\begin{array}{l}0,202 \\
-0,148\end{array}$ & $\begin{array}{l}0,222 \\
0,170\end{array}$ & $\begin{array}{l}0,451 \\
-0,103\end{array}$ & $\begin{array}{l}0,308 \\
-0,078\end{array}$ & $\begin{array}{l}0,431 \\
-0,185\end{array}$ & $\begin{array}{l}0,365 \\
-0,097\end{array}$ & $\begin{array}{l}0,191 \\
0,055\end{array}$ & $\begin{array}{l}0,262 \\
-0,119\end{array}$ & $\begin{array}{l}0,333 \\
-0,125\end{array}$ & $\begin{array}{l}0,049 \\
-0,024\end{array}$ & $\begin{array}{l}0,012 \\
-0,200\end{array}$ & $0,132^{*}$ & 1 & \\
\hline SSML & $\begin{array}{l}\text { Sig. } \\
\text { Correlation } \\
\text { Coefficient }\end{array}$ & $\begin{array}{l}0,486 \\
-0,247^{*}\end{array}$ & $\begin{array}{l}0,280 \\
0,087\end{array}$ & $\begin{array}{l}0,158 \\
-0,061\end{array}$ & $\begin{array}{l}0,124 \\
0,077\end{array}$ & $\begin{array}{l}0,237 \\
-0,181\end{array}$ & $\begin{array}{l}0,294 \\
-0,124\end{array}$ & $\begin{array}{l}0,099 \\
-0,236^{*}\end{array}$ & $\begin{array}{l}0,251 \\
-0,188\end{array}$ & $\begin{array}{l}0,351 \\
0,167\end{array}$ & $\begin{array}{l}0,206 \\
0,046\end{array}$ & $\begin{array}{l}0,191 \\
-0,248^{*}\end{array}$ & $\begin{array}{l}0,435 \\
-0,023\end{array}$ & $\begin{array}{l}0,082 \\
-0,380^{* *}\end{array}$ & $\begin{array}{l}0,047 \\
-0,109\end{array}$ & 0,096 & 1 \\
\hline \multirow[t]{2}{*}{ SSYL } & $\begin{array}{l}\text { Sig. } \\
\text { Correlation } \\
\text { Coefficient }\end{array}$ & $\begin{array}{l}0,045 \\
0,025\end{array}$ & $\begin{array}{l}0,279 \\
0,017\end{array}$ & $\begin{array}{l}0,339 \\
-0,105\end{array}$ & $\begin{array}{l}0,302 \\
-0,016\end{array}$ & $\begin{array}{l}0,104 \\
-0,001\end{array}$ & $\begin{array}{l}0,195 \\
0,002\end{array}$ & $\begin{array}{l}0,050 \\
0,021\end{array}$ & $\begin{array}{l}0,096 \\
0,024\end{array}$ & $\begin{array}{l}0,124 \\
-0,045\end{array}$ & $\begin{array}{l}0,375 \\
-0,170\end{array}$ & $\begin{array}{l}0,040 \\
-0,122\end{array}$ & $\begin{array}{l}0,437 \\
-0,016\end{array}$ & $\begin{array}{l}0,003 \\
0,086\end{array}$ & $\begin{array}{l}0,083 \\
0,006\end{array}$ & $\begin{array}{l}0,111 \\
0,115\end{array}$ & $-0,085^{*} 1$ \\
\hline & Sig. & 0,433 & 0,455 & 0,238 & 0,457 & 0,496 & 0,493 & 0,443 & 0,435 & 0,378 & 0,119 & 0,197 & 0,454 & 0,276 & 0,471 & 0,073 & 0,001 \\
\hline
\end{tabular}

LSML (leaf surface of mature leaf); LSYL (leaf surface of young leaf); SLAML (specific leaf area of mature leaf); SLAYL (specific leaf area of young leaf); FWML (fresh weight of mature leaf); FWYL (fresh weight of young leaf); DWML (dry weight of mature leaf); DWYL (dry weight of young leaf); WCML (water content of mature leaf); WCYL (water content of young leaf); CCML (chlorophyll content of mature leaf): CCYL (chlorophyll content of young leaf); TR (transpiration rate); NSML (number of stomata in mature leaf); NSYL (number of stomata in young leaf); SSML (size of stomata in mature leaf); SSYL (size of stomata in young leaf)
$*$ *. Correlation is significant at the 0.01 level (1-tailed). *. Correlation is significant at the 0.05 level (1-tailed) 


\section{CONCLUSION}

In conclusions, this study suggests that leaf growth and development in loquat seedling was affected on the types of PGR and doses applied. Auxin, gibberellin and cytokinin was an important hormone during leaf growth and development. Either in mature or young leaves, PGR's was significantly affecting the growth and development of leaves. However, PGR's was only not significantly affecting to the number of stomata in young leaves. The application of PGR doses was not always in line with the mean value of each parameter, and probably it could be linear or quadratic models. In order to determine the growth and development of leaf, it is necessary to know the correlation from each parameter and the interaction between each PGR. This conclusion provides an information for PGR application during the production of loquat seedling.

\section{ACKNOWLEDGEMENTS}

The authors are thanks to the local government in Danau Toba, North Sumatra-Indonesia. This study was supported by Research Center for Biology, Indonesian Institute of Sciences through IBSAP 2019 project.

\section{COMPETING INTERESTS}

Authors have declared that no competing interests exist.

\section{REFERENCES}

1. Lin S, Sharpe $\mathrm{RH}$, Janick J. Loquat: Botany and horticulture. Horticultural Reviews. 1999;23:233-276.

2. Talluto G, Gugliuzza G, Massenti R, Lo Bianco R. Growth and biomass partitioning of young loquat plants under water deficit. Acta Horticulturae. 2015;1092:199-204.

3. Shahi-Gharahlar A, Yavari AR, Khayyat M, Jalali N, Farhoudi R. Effects of soaking temperature, stratification, potassium nitrate and gibberellic acid on seed germination of loquat trees. Journal of Plant Nutrition. 2012;35(11):1735-1746.

4. Caballero $\mathrm{P}$, Fernández MA. Loquat, production and market. Options Mediterraéens, Serie A. Seminaires Mediterranéens. 2003;58:11-20.

5. Li X, Xu C, Chen K. Nutritional composition of fruit cultivars: Loquat (Eriobotrya japonica Lindl.). In: Nutritional composition of fruit cultivars. Academic, San Diego; 2016.

6. Liu Y, Zhang W, Xu C, Li X. Biological activities of extracts from loquat (Eriobotrya japonica Lindl.): A review. International Journal of Molecular Sciences. 2016;17(12):1-15.

7. Davies PJ. The plant hormones: Their nature, occurrence and functions. In: Davies PJ (Eds) Plant Hormones. Springer, Dordrecht; 2010.

8. Souza GM, Prado CHBA, Ribeiro RV, Paulo J, Barbosa RAD, Goncalves AN. Toward a systemic plant physiology. Theoretical and Experimental Plant Physiology. 2016;28(4):341-346.

9. Rademacher W. Plant growth regulators: Backgrounds and uses in plant production. Journal of Plant Growth Regulation. 2015;34:845-872.

10. Peleg Z, Blumwald E. Hormone balance and abiotic stress tolerance in crop plants. Current Opinion in Plant Biology. 2011;14(3):290-295.

11. Taiz L, Zeiger E. Plant physiology, $3^{\text {rd }}$ Ed. Sinauer Associates Inc Publishers. Sunderland; 2002.

12. Wright IJ, Reich PB, Westoby M, Ackerly DD, Baruch Z, Bongers F, Cavender-Bares $\mathrm{J}$, Chapin T, Cornelissen JH, Diemer M, Flexas J. The worldwide leaf economics spectrum. Nature. 2004;428(6985):821827.

13. Koch GW, Sillett SC, Jennings GM, Davis SD. The limits to tree height. Nature. 2004;428:851-854.

14. Tozer WC, Rice B, Westoby M. Evolutionary divergence of leaf width and its correlates. American Journal of Botany. 2015;102:367-378.

15. Franks PJ, Beerling DJ. Maxiumum leaf conductance driven by $\mathrm{CO}_{2}$ effects on stomatal size and density over geologic time. Proceeding of the National Academy of Science of the United States of America. 2009;106(25):10343-10347.

16. Taylor SH, Franks PJ, Hulme SP, Springs E, Christin PA. Photosynthetic pathway and ecological adapation stomatal trait diversity amongst grasses. New Phytologist. 2010;193(2):387-396.

17. Oyeleke MO, Abdulrahaman A, Oladele FA. Stomatal anatomy and transpiration rate in some afforestation tree species. NISEB Journal. 2014;4(2):83-90. 
18. Dodd IC. Hormonal interactions and stomatal responses. Journal of Plant Growth Regulation. 2003;22(1):32-46.

19. Beghin T, Cope JS, Remagnino P. Shape and texture based plant leaf classification. In: Advanced Concepts for Intelligent Vision Systems, Berlin Heidelberg: Springer; 2010.

20. Miyazawa SI, Livingston NJ, Turpin DH. Stomatal development in new leaves is related to the stomatal conductance of mature leaves in poplar (Populus trichocarpa $\times P$. deltoides). Journal of Experimental Botany. 2006;57(2):373380.

21. Lakshmipathi JD, Kalaivanan D, Halesh GK. Effect of plant growth regulators on leaf area, chlorophyll content, carotenoids, stomatal count and yield of cashew (Anacardium occidentale L.) var. Bhaskara. Journal of Plantation Crops. 2017;45(2):141-146.

22. Bailey LF, Rothacher JS, Cummings WH. A critical study of the cobalt chloride method of measuring transpiration. Plant Physiology. 1951;27(3):563-574.

23. Bishnoi NR, Krishnamoorthy HN. Effect of gibberelic acid on stomatal diffusive resistance and photosynthesis in waterlogged peanut plants. Biologia Plantarum. 1993;35:467.

24. Nobel PS, Zaragoza LJ, Smith WK. Relation between mesophyll surface area, photosynthetic rate and illumination level during development for leaves of Plectranthus parviflorus Henckel. Plant Physiology. 1975;55(6):1067-1070.

25. Miceli A, Moncada A, Sabatino L, Vetrano F. Effect of gibberellic acid on growth, yield and quality of leaf lettuce and rocket grown in a floating system. Agronomy. 2019;9(7): 382.

26. Lambers $\mathrm{H}$, Nagel OW, Van Arendonk JJCM. The control of biomass partitioning in plants from favourable and stressful environments: A role for gibberellins and cytokinins. Bulgarian Journal of Plant Physiology. 1995;21(2-3):24-32.

27. Dwyer PJ, Bannister P, Jameson PE. Effects of three plant growth regulators on growth, morphology, water relations and frost resistance in lemonwood (Pittosporum eugenioides A. Cunn). New Zealand Journal of Botany. 1995;33(3): 415-424.

28. Mbandlwa NP, Fotouo-MH, Maboko MM, Sivakumar D. Stomatal conductance, leaf chlorophyll content, growth and yield of sweet pepper in response to plant growth regulators. International Journal of Vegetable Science. 2020;26(2):116-126.

29. Chaudhry NY. Effect of growth hormones i.e., IAA, kinetin and heavy metal ie, lead nitrate on the internal morphology of leaf of Phaseolus vulgaris L. Pakistan Journal of Biological Sciences. 2003;6(2):157162.

30. Di Benedetto A, Galmarini C, Tognetti J. Effects of combined or single exogenous auxin and/or cytokinin applications on growth and leaf area development in Epipremnum aureum. The Journal of Horticultural Science and Biotechnology. 2015;90(6):643-654.

31. Savaldi-Goldstein S, Chory J. Growth coordination and the shoot epidermis. Current Opinion in Plant Biology. 2008;11: 42-48.

32. Jones HG. Stomatal control of photosynthesis and transpiration. Journal of Experimental Botany. 1998;49:387398.

33. Kumar B, Pandey DM, Goswami CL, Jain S. Effect of growth regulators on photosynthesis, transpiration and related parameters in water stressed cotton. Biologia Plantarum. 2001;44(3):475-478.

34. Schubert J, Roeser K, Grossman K, Sauter $\mathrm{H}$, Jung J. Transpiration-inhibiting abscisic acid analogs. Journal of Plant Growth Regulators. 1991;10:27-32.

35. Kuldeepsingh AK, Singh AL, Goswami N, Mehta D, Mahatma MK, Ajay BC, Chakraborty K, Zala PV, Chaudhary V, Patel CB. Photosynthetic characteristics of peanut genotypes under excess and deficit irrigation during summer. Physiology and Molecular Biology of Plants. 2015;21(3): 317-327.

36. Cechin I, Rossi SC, Oliveira VC, Fumis TDF. Photosynthetic responses and proline content of mature and young leaves of sunflower plants under water deficit. Photosynthetica. 2006;44(1):143.

37. Zhang $X$, Jun ZHU, Cheng $S$, Zhang WW, Feng XU, Yongling LIAO. Effect of exogenous gibberelin on endogenous hormone and ginkgolide content in Ginkgo leaves. Notulae Botanicae Horti Agrobotanici Cluj-Napoca. 2020;48(1):140149.

38. Acharya BR, Assmann SM. Hormone interactions in stomatal function. Plant Molecular Biology. 2009;69:451-462. 
39. Sun TP, Gubler F. Molecular mechanism of gibberellin signaling in plants. Annual Reviews of Plant Biology. 2004;55:197223.
40. Weis D, Ori N. Mechanisms of cross talk between gibberellin and other hormones. Plant Physiology. 2007;144: 1240-1246.

(9) 2020 Surya et al.; This is an Open Access article distributed under the terms of the Creative Commons Attribution License (http://creativecommons.org/licenses/by/4.0), which permits unrestricted use, distribution, and reproduction in any medium, provided the original work is properly cited.

Peer-review history:

The peer review history for this paper can be accessed here:

http://www.sdiarticle4.com/review-history/62125 